Tension normal. There was $20^{\circ}$ divergence of the right eye, the left being the fixing eye. Fields were full sized but there was a considerable relative scotoma enlarging the blind spot temporally. Color fields were normal.

Ophthalmoscope. Right cye. Revealed a dense white mass occupying the center of the vitreous (retinitis proliferans), the remainder of the vitreous containing many large and small opacities. The region of the macula was fairly distinct and portions of retinal vessels could be distinctly seen in various portions of the field. The disc was completely obscured as was also the patch of choroidal atrophy referred to.

Left eye. Many large and small vitreous opacities but no definitely organized mass. No fundus details discernible.

\title{
THE SPECIFIC PRECIPITIN REACTION OF THE LENS.
}

\section{Ludvig Hektoen, M.D.}

\author{
CIIICAGO, ILLINOIS.
}

This paper sets forth the facts regarding the specific reaction of the higher vertebrates to crystalline lens substance. This is essentially the same whatever the species from which the lens is obtained. Read before the Chicago Ophthalmological Society, May 26, 1921.

It was discovered by Uhlenhuth that the lens of different species gives the same immune reactions. A lens antiserum, produced let us say by injecting a rabbit or guinea-pig with beef lens, will react in precipitation, anaphylaxis and complement fixation tests not only with beef lens but also with the lens of other mammals, of birds, and of amphibians. With fish lens the reaction, however, is very faint. The specificness of the reaction is determined not by species, as in other immune reactions (blood, scrum, bacteria), but by the organ from which the antigen is derived as illustrated by this scheme:

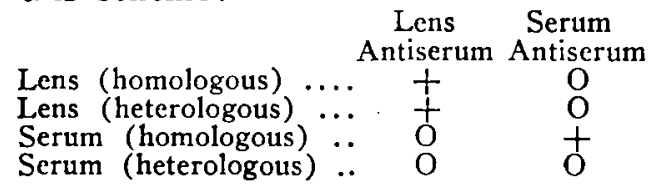

So far the lens is the only clean cut example we have of this organspecificness as contrasted with speciesspecificness in antigen-antibody reactions.

I have studied the precipitins that develop in rabbits on the injection of lens solutions in $0.9 \%$ salt solution; approximately 10 or $20 \%$ solutions by weight of beef, horse, rabbit, sheep and swine lens, removed with special care to avoid admixture with blood or serum, have been used. As a rule four or five injections of lens solution are given intravenously at four day intervals, first $2-4$ c.c., increasing gradually to $12-16$ c.c. The highest titer of the serum is reached about the eighth day after the last injection. Most of my work has been with antiserums that would cause precipitates in lens dilutions of at least 1 to 5000 and often much higher. The injection of rabbits with solutions of rabbit lens, however, does not have the same antigenic effect as the injection of lens of other species, and as contradictory results are reported on this point, further study is required.

Table 1 shows that all the lens solutions used (beef, chicken, dog, guineapig, horse, human, monkey, rabbit, rat, sheep, swine) react in the same way with beef lens antiserums; further that this antiserum does not react with the serum of beef blood or of the other species represented and conversely that beef serum antiserum does not react with any lens solution. The organspecificness of the lens holds good thruout and the lens does not appear to contain any species-specific antigens. Horse, sheep, and swine lens antiserums have precisely the same effects as beef lens antiserum.

The aqueous and vitreous humors contain lens substance because these fluids in low dilutions or full strength react with lens antiserums. These hu- 
mors react with serum antiserum also -not always-and then the law of species-specificness obtains. The presence of lens substance in the humors is interesting and the question arises whether the lens substance in the humors is derived from the lens or on the way to be incorporated into the lens.

Table 1 also shows that the serum of a rabbit injected with extract of beef cornea reacts with beef serum, beef vitreous, and beef aqueous, but not at all with beef lens or any other lens, indicating that the cornea contains species-specific proteins only.

We see then that the precipitin reactions of the lens of certain mammals are lens-specific and that the lens does not appear to contain any speciesspecific precipitinogens, hence the lens protein may be regarded as chemically distinct and as identical in diverse species.

Note-The precipitation in sheep viterous horse and sheep serums by beef serum antiserum and beef cornea antiserum are examples of species-specific reactions extending over to related species.
LENS PRECIPITIN REACTIONS

\begin{tabular}{|c|c|c|c|}
\hline & $\begin{array}{l}\text { Beef Lens } \\
\text { Antiserum }\end{array}$ & $\begin{array}{c}\text { Beef } \\
\text { Serum } \\
\text { Antiserum }\end{array}$ & $\begin{array}{c}\text { Beef } \\
\text { Cornea } \\
\text { Antiserun }\end{array}$ \\
\hline Beef Lens & + & $\mathrm{O}$ & $\mathrm{O}$ \\
\hline Chicken Lens & + & $\mathrm{O}$ & $\mathrm{O}$ \\
\hline Dog Lens. & + & $\mathrm{O}$ & $\mathrm{O}$ \\
\hline G. Pig Lens & + & $\mathrm{O}$ & $\mathrm{O}$ \\
\hline Horse Lens & & $\mathrm{O}$ & $\mathrm{O}$ \\
\hline Human Lens & + & $\mathrm{O}$ & $\mathrm{O}$ \\
\hline Monkey Lens & $t$ & o & $\mathrm{O}$ \\
\hline Rabbit Lens & + & $\mathrm{O}$ & $\mathrm{O}$ \\
\hline Rat Lens & & $\mathrm{O}$ & $\mathrm{O}$ \\
\hline Sheep Lens & + & $\mathrm{O}$ & $\mathrm{O}$ \\
\hline Swine Lens & + & 0 & $\mathrm{O}$ \\
\hline Beef Aqueous & + & + & + \\
\hline Dog Aqueous & + & 0 & $\mathrm{O}$ \\
\hline Human Aqueous & + & $\mathrm{O}$ & $\mathrm{O}$ \\
\hline Rab't Aqueous & + & $\mathrm{O}$ & $\mathrm{O}$ \\
\hline Sheep Aqueous & + & $\mathrm{O}$ & $\mathrm{O}$ \\
\hline Swine Aqueous & + & $\mathrm{O}$ & $\mathrm{O}$ \\
\hline Beef Vitreous & + & + & $t$ \\
\hline Dog Vitreous & & $\mathrm{O}$ & O \\
\hline Human Vitreous & $t$ & $\mathrm{O}$ & $\mathrm{O}$ \\
\hline Rab't Vitreous & + & O & $\mathrm{O}$ \\
\hline Rat Vitreous & $t$ & $\mathrm{O}$ & $\mathrm{O}$ \\
\hline Sheep Vitreous & + & + & $t$ \\
\hline Swine Vitreous & + & $\mathrm{O}$ & 0 \\
\hline Beef Serum & O & + & + \\
\hline Horse Serum & $\mathrm{O}$ & & + \\
\hline Human Serum & 0 & $\mathrm{O}$ & $\mathrm{O}$ \\
\hline Monkey Serum & $\mathrm{O}$ & $\mathrm{O}$ & $\mathrm{O}$ \\
\hline Rab't Scrum & $\mathrm{O}$ & $\mathrm{O}$ & $\mathrm{O}$ \\
\hline Sheep Serum & $\mathrm{O}$ & t & $t$ \\
\hline Swine Serum & $\mathrm{O}$ & 0 & O \\
\hline Beef Cornea & $\mathrm{O}$ & + & + \\
\hline
\end{tabular}

